\title{
Magsud Ibrahimbeyov's Let Him Stay with Us Through the Post-Soviet Union and Western Lenses
}

\author{
Leyla Seyidova \\ MacEwan University
}

It is easy to translate a work word for word into another language. The task becomes much more difficult when one contemplates how the words of the translation will sound in the target language and considers any cultural background that those words may have. In fact, an accurate literal translation may make no sense, or even be offensive in the target language. As Oksana Zabushko writes, "in some cases, opting for vocabulary more recognizable to English-language readers might lead not only to semantic but also ideological losses in translation" (88). In other words, one must translate meanings, not words.

In this essay, I will examine how Magsud Ibrahimbeyov's Russian-language novella Let Him Stay with Us, translated by Saadat Ibrahimova, changes, gains, and loses meaning when translated to English, and the translation's effect on the readers' interpretation of the novella. Translations always obscure the original meaning, but they can provide insight into both post-Soviet Azeri and Western cultures. I will first discuss the original Russian text. Then, I will demonstrate the impossibility of an exact translation of texts due to different grammatical, syntactical, and idiomatic language structures. Finally, I will examine the translated English text while demonstrating how post-Soviet and Western audiences might interpret the translation and how the language of a translation reflects its culture.

Ibrahimveyov was born in Baku, Azerbaijan in 1935 and remains one of the most prominent authors and screenwriters of Azerbaijan. After receiving his B.A. in Civil Construction in 1960, he began focusing on literary studies and writing. In 1964, he attended masterclasses for screenwriters and directors in Moscow. Since then he became known as a Russophone Azerbaijani writer.

Ibrahimbeyov wrote his works in Russian, which reveals the colonial and totalitarian context of his writing. That is, although he lived in Azerbaijan, due to the country's belonging to the Soviet Union, Ibrahimbeyov was forced to write in the language of the politically dominant culture. In much the same way, the English language currently functions as an outlet for international literature to become known worldwide. Zabushko writes that "George Steiner [...] describes the English language as an 'indispensable window on the world' [...] They [works] must be translated if their works, if their lives, are to have a fair chance of coming into the light" (197). In other words, in order for Ibrahimbeyov's works to "share their [his works'] capital and gain popularity," (Venuti 17) he must write in the colonizer's language-Russian. Interestingly, despite the strict Soviet regime, Ibrahimbeyov's rate of written work decreased after the fall of the USSR. For example, during the Soviet period, he wrote thirteen prose texts and five dramatic scripts whereas after its fall, Ibrahimbeyov wrote only two prose 
texts and three scripts. There is no clear evidence as to why Ibrahimbeyov wrote less after the collapse of the Soviet Union, but I speculate that he Soviet Union may have caused Ibrahimbeyov's decline in creative output due to a lack of writing subject matter and trauma after the fall of the USSR. That is, Azerbaijan's economic and social states rapidly declined after the fall of the Soviet empire. This recession occurred partly because the export of Azerbaijani oil declined significantly following the fall of the Soviet Union. Under the Soviet Union, Ibrahimbeyov's stories involved union and harmony between families, however, writing about such subjects after the fall would seem unrealistic. Despite his linguistic choice, which was conditioned by the Soviet reality, Ibrahimbeyov remains a true popular writer in Azerbaijan. Most of his stories were set in his beloved Baku city. Ibrahimbeyov finds deep meaning in mundane details and conveys it in a simple and plain language, as the novella discussed here will show.

Let Him Stay with Us, one of Ibrahimbeyov's major works, is a novella that was published in 1976 and translated into English in 2005. As is common in many of Ibrahimbeyov's works, it does not have a named protagonist. That is, the reader understands the protagonist's identity, who is usually the narrator, from the narrative. However, the author does not always provide clear indications to establish the protagonist. The protagonist's anonymity generalizes Azeri men, making the male protagonist any and every man in Azerbaijan. Let Him Stay with $U s$ is not an exception, since the narrator is an unnamed boy about 14 years old. The protagonist, to whom I will refer as the 'boy' or the 'narrator,' lives with his strict and callous father and gentle grandmother, who is his deceased mother's mother. The novella portrays the father as a good man who takes care of his family; the narrator, however, craves his father's attention and love. In the middle of the novella, a circus arrives in town. The lions' escape into the city marks the text's climax. Upon trying to escape his house because he can no longer endure his father's neglectful attitude towards him and his grandmother, the boy finds one of the lions at his gate. Instead of following through with his escape, he takes the lion home, and asserts his intention of keeping him alive, despite his father's command to kill the animal. Through his rebellion, the boy matures and becomes himself the head of the household. The lion and the narrator build a mutually understanding relationship. The novella concludes with the father coming home to find his son in the same room as the lion. The lion is taken to the zoo and the father embraces his son and mother-in-law.

By introducing a lion in the middle of the story, the novella demonstrates that if we treat others with kindness, that is, if the father were to show affection towards his son, even lions can become our friends. However, the lion also reveals a moment of transformation for the son, whereupon he becomes a "man" and thus the father starts to respect him. The question of being a man or being a "good man" is at the centre of many of Ibrahimbeyov's works. As Venuti writes, "Any text [...] varies in form, meaning, and effect according to the different contexts in which it is situated" (5-6). That is, the implications, ramifications, and cultural circumstances of the novella depend on the cultural context of the text. In other words, the context of the novella is essential to understanding how 
translations of this text show cultural differences and how Post-Soviet, Eastern, and North American cultures interpret this text.

To better demonstrate the specific cultural differences of Azeri versus North American culture, I will give a personal example. I was born and raised in Baku, Azerbaijan, but have lived in Canada for the last eight years. In the summer of 2019, my family visited the country for a few weeks. I can vouch that almost nothing has changed in our culture and the book remains accurate in its depiction of an Azeri man. As a Canadian, I am used to being able to walk outside in daytime more or less without having to worry about my safety. One day, I told my grandparents that my female cousin and I would go for a walk at the beach, which was nearby our house. My grandfather and uncle both frowned and said that I could not go in the tank top and shorts I was wearing, despite it being +42 degrees outside, and that a man must accompany us. I was furious at this suggestion, but my cousin reminded me that it reflected the norm in Azeri culture. I had the same feeling when reading Irahimbeyov's novels in the original and in translation, because as a North American, I was angry at the fact that what the author depicts is a reality that must be tolerated by many Azeri people. However, I also understand that it is the only culture Ibrahimbeyov has been exposed to his entire life. In other words, Ibrahimbeyov's novella is seen as normal in Azerbaijan, whereas in Canada it is read as highly sexist and problematic.

Before examining the translation's effect on a Western audience, it is important to examine the grammatical/linguistic differences between Russian and English, because Slavic and Germanic language groups vary greatly. Russian and English come from different language groups: Russian from the Slavic language family and English from the Germanic language family. One of the main differences between English and Russian is that the latter is inflectional. That is, Russian uses a single inflectional morpheme to denote multiple grammatical, syntactic, or semantic features, instead of having a separate affix for each feature. This allows the Russian language to alternate the subject and the object of the sentence without compromising its active or passive voice. Furthermore, the alternation of the subject and the object causes a shift in emphasis of the sentence's subject. For instance, if one says in English, "Jim hit Bob" and "Bob was hit by Jim," the English grammar must include "was hit" to indicate the subject and object of the sentence. In Russian, however, it would be "Jim udaril Boba" and if one reverses the order in which the subject and the object appear, the sense remains unchanged, because there is the 'a' ending on Bob's name. The inflection determines the role of the word in a sentence, so whether a word is at the end or at the beginning of the sentence, its role is determined by the inflection.

The syntactical differences between Russian and English shed light on the bigger question of the Soviet and Western cultures' understanding of Ibrahimbeyov's work and how the translation reflects Western culture's thought. As Venuti writes, "Any text is a complex cultural artifact, supporting meanings, values, and functions that are indivisible from its originary language and culture" (8). That is, just the fact that a text is translated means that a translator, or as Venuti refers to them, 
"agents who traffic the foreign" (22), has made a choice to interpret it in a certain way. Consequently, the original text has lost and gained meaning. In other words, during translation, "change is unavoidable" (Venuti 8). The novella reveals numerous words and phrases that lose layers of meaning when translated into English. For instance, sometimes it takes a sentence in English to describe one Russian word. The English text translates a Russian idiom simply into a noun. For example, the Russian idiom “Курам на смех!” ((Ибрагимбеков 382) becomes “They're joking!” (Ibrahimbeyov 25) in English. The literal translation would be "It makes chicken laugh," which lacks any sense in English. Consequently, the translator must reduce the meaning to "They're joking!" which demonstrates the impossibility and loss of meaning during translation. In addition, the Russian expression "shivorot na vivorot" (Ibrahimbeyov 373) is translated into English as "collar" (Ibrahimbeyov 13). In reality, the Russian idiom's meaning refers to a piece of clothing that is worn inside out or is not properly worn. The English translation reduces the Russian idiom's meaning. However, one could argue that the lack of understanding of the idiom does not impede from understanding the rest of the sentence. That is, not knowing the idiom's exact meaning allows one to understand the sentence's overall meaning. However, I argue, that although the reader's ignorance of the specific definition of the Russian idiom does not impair his or her understanding of the text, it takes away from the enriching and descriptive details of the text. As in the previous one, the following example reveals how the text loses meaning when translated to English: "И морда у него в это время была очень наглая, как раз такая, по которой хочется изо всех сиц стукнуть" (Ibrahimbeyov 370) becomes "And his expression was so obnoxious, you just wanted to smack him in the mug" (Ibrahimbeyov 11). The Russian noun "мopaa" means an animalistic face, similar to the word "gueule" in French. It constitutes a dehumanizing and offensive way to note someone's face. Despite the original word's negative connotation, the English text translates it into a neutral noun "expression." As a result of the reduction and loss in meaning in the English translation, the reader has a limited understanding of the text. That is, he or she will be aware of the general context, but will lack understanding of the original text's finite details due to the impossibility of a literal translation.

Besides the differences in words and phrases, sentence structure also varies amongst the three languages. As Shchennikova writes (114), “Английское речевое мышление характеризуется большей абстрактностью, чем русское.” [“English speech thinking is more abstract than Russian”]. ${ }^{1}$ To explain, a grammatically correct traditional sentence in Russian is usually considered too long and overflowing with information for English. Venuti argues that "Not only should meaning be comprehended, all too likely to be reduced to the source text, but form should be critically appreciated, the features of register, style, and discourse that uniquely characterize the translating language" (20). Venuti suggests that, although interpretations work to appeal to an audience, translations must keep the form of the original text. However, doing so can be problematic to an audience that is not accustomed to reading in a radically different syntactic form. The following quote from the novel exemplifies the latter statement:

\footnotetext{
${ }^{1}$ My translation.
} 
Grandma was disconcerted, she gets upset easily, and said that she had lived in the apartment through her life with her late husband, she meant my grandfather, and all her life she has had the best furniture in Karelian birch and there had even been a harmonium, but never a safe and, to speak quite frankly, she had never heard until that day of a safe in a home, never mind where it should stand, and at her age she had no desire to know. (Ibrahimbeyov 17) ${ }^{2}$

Reading the single English sentence feels claustrophobic because it is packed with information. Successive phrases reveal the grandmother's character, her life with her deceased husband, the type of furniture she had, and her lack of knowledge regarding safes. Moreover, the English sentence is visually shorter in length than the original one, because the translation eliminates the details. For example, the original sentence includes "сразу же," meaning "immediately," which the English translation omits. In addition, the Russian text mentions that the grandmother was disconcerted or upset "на папу," that is, with the father. The English translation does not include that detail, as it simply states that "she [grandmother] gets upset easily." The English translation seems to condense the original text, as it emphasizes the events, rather than their details. The novella and its translation reflect the difference in cultural thought through the loss of details, but with the details a deeper meaning of the story is also lost in the English translation. For instance, when reading the novella, I found the original Russian version easier to read and understand than the English translation, despite English being the language in which I think and work. In my opinion, the Russian style of writing is more engaging due to its details, whereas the English translation seems like a factual account of events. The English translation deals with the 'what' of the narrative, while the Russian examines the 'how' and 'why'. It is less what is said which holds importance than the way it is said in Russian. Venuti explains, "Interpretants [...] decisively assimilate the source text to what is intelligible and interesting to receptors-or else the resulting translation fails to be viable" (11). In other words, the English interpretation is meant to appeal to an English-speaking audience. However, the English translation creates a different effect on the readers of the novel, because they will not discover the entire narrative, but rather a bare chronology of events. For example, during the circus performance, the protagonist narrates: "Этот фокусник поставиц посередине арены столик, а на него ящик, чтобы было видно, что этот ящик с полом не соединяется” (Ибрагимбеков 388), which becomes “This magician put a table in the middle of the ring, and a box on it, showing that the box wasn't connected to the floor" (Ibrahimbeyov 33). The English version translates “чтобы было видно" as "showing," when it means "so that it could be seen." The translation employs a shorter and a more concise word to translate the original. The concision of the English translation lacks the asides, the details, and the figurative language that the Russian text offers. In contrast, a Russian reader will read through those

\footnotetext{
2 “Бабушка сразу же разобилелась, на папу она очень мегко обижается, и сказала, што у нее в прежней квартире при жизни ее покойново мужа, это значит моего Аеда, всю жизнь была самая мучшая мебель из капельской березы и даже стояла фисгармония, но сейфа не было, а если говорить совсем откровгенно, то она Ао этово Аня никогАа в жизни и не слышала, што в квартире может стоять сейф, а уж гАе он должен стоять, она подавно не знает, а на старости кет и узнать это никакого желания не испытывает” (Ибрагимбеков 376).
} 
same chronological events as a detailed account, which will enrich his or her reading and understanding of the text.

At first, the differences in translation may seem minor; however, the fact that in the original text, sentences are longer suggests not only how people speak, but more importantly how they think. As Sharipova writes (1), “Язык, речь, речевая деятельность принадлежат области неосознаваемого и в то же время явАяются необходимым инструментом сознательного отражения. Они отражают концептуальную картину мира своего носителя, его менталитет национальный способ видеть и понимать мир" ["Language, speech, and speech activity belong to the field of the unconscious and at the same time are a necessary tool for conscious reflection. They reflect the conceptual picture of the world of its carrier, its mentality is a nationally distinct way to see and understand the world"]. ${ }^{3}$ That is, in post-Soviet and Eastern countries, people think profoundly even about simple things. For instance, if a Russian individual is asked a simple question, such as, "Why did you read this novel?" the person will start with a philosophical quotation or idiomatic phrase and only after about five minutes may or may not answer the question. However, if the same question is asked in Canada, it would receive a direct answer. It must be acknowledged that such differences in responses are individual, but general cultural differences can be seen in one text and its translation. The example noted above demonstrates that the Russian text is filled with sentences packed with information, which are considered as overloaded by North American standards. For example, in the story, the English translation splits the original due to its length, where "Я смотрец и удивлялся, что оно такое у него усталое и даже измученное, видно было, что и глаза у него были уставшие, несмотря на то что, они были закрыты” (Ибрагимбеков 446) becomes [“I looked and was surprised that he seemed so tired, even exhausted. Although his eyes were closed, you could see they were tired" (Ibrahimbeyov 112)]. Although dividing the Russian sentence into two parts makes it easier to comprehend, it also takes away from the flow and details of the original sentence. In a broader sense, in Russia, people pay more attention to small everyday details and problems whereas, in Canada, only the big picture matters and those details are usually not acknowledged. As Schennikova writes (1), "Native Russian speakers tend to copy the native system of morphological and semantic-syntactic patterns in their English speech, which results in deviations from the authentic English norms". "The translation of Ibrahimbeyov's novella shows how translation reflects language, which echoes a people's culture and its thoughts.

Just as a Russian-speaking individual may not have a simple answer to the question "Why did you read this novel?", there is no simple answer to the question of how linguistic discrepancies affect post-Soviet and Western acceptance and understanding of Ibrahimbeyov's text. That is, the story's original and translated texts differ not only on the linguistic level of syntax and vocabulary, but also on a semantic level, in the different values and thoughts of the languages' respective cultures. The

\footnotetext{
${ }^{3}$ My translation.

${ }^{4}$ My translation
} 
story's ending adds to the problematic sexist dynamic of the text, since at the end of the story, the father hugs his son in front of his community, and later the grandmother joins the embrace. For a Western audience, the ending may not seem satisfying and the father may not have seemed to deserve the opportunity to finally show affection to his child after several years of neglecting him. In other words, the softening of the male character at the end of the story may not satisfy a Western audience. Through the father's character, however, Ibrahimbeyov contests the stereotypical Azeri male figure. That is, he challenges the image of a man as someone who shows no emotion, is callous and strict. This type of male character is common in Ibrahimbeyov's works, because he usually juxtaposes a male character who fulfills all of the male stereotypes, and another male character who breaks the stereotypes, but ends up a good human being at the end. To further explain, to a Western audience, the story and especially its ending may seem sexist, however, to a Russian audience the ending may seem quite typical and expected. This is to say that translations can seem problematic, as was the case with Let Him Stay with Us, due to the reader's lack of understanding of a certain culture. As Venuti writes, "translation is a practice that mediates between cultures" (23), meaning that it is not as important to translate the literal meaning of a work, which is sometimes impossible due to linguistic differences, as it is to translate the work's cultural meaning. As a result, the translation of cultures will enable a transnational understanding of a work. Through translation, Ibrahimbeyov's novella allows for an understanding of the post-Soviet Azeri culture by a Western audience. However, due to the lack of an exact translation, the original text loses meaning. In addition, the Western audience's lack of awareness of Azeri culture, such as an emphatic insistence on gender roles, makes the novella seem problematic, whereas a Russian audience would consider it normal. Thus, the English translation of Ibrahimbeyov's Let Him Stay with Us produces a problematic interpretation for a Western audience. 


\section{REFERENCES}

Ibrahimbeyov, Magsud. Let Him Stay with Us. Translated by Saadat Ibrahimova. Magsud Ibrahimbeyov Creativity Centre 2018.

Sharipova V. "About the Conceptualization and Objectification (Verbalization) of Concepts in a Language as the Essential Processes of Homo Loquens Speech Activity (using the materials of comparative research of Russian and English verbs of speaking)" Вестник Кемеровского государственного университета. 2015, Vol 0, No. 4-1, pp. 186-190.

Shchennikova, Natalya. "English speech thinking is more abstract than Russian" Vestnik IKBFU. 2014, Issue 2, pp. 106-116.

Steiner, George. No Passion Spent: Essays 1978-1996. Faber and Faber, 1996. Print.

Venuti, Lawrence. "Translation, Interpretation, Canon Formation." Translation and the Classic, 2008 pp. $27-51$.

Zabushko, Oksana. Fieldwork in Ukranian Sex. Trans. Halyna Hryn. Amazon Crossing, 2011.

\section{Foreign Language Works Cited}

Ибрагимбеков, Максуа. И не бъло лучше брата. Москва Вагриус, 2005. [And there was no better brother]

“Ибрагимбеков, Максуд Мамед Ибрагим Оглы.” Wikipedia, Wikimedia Foundation, 26 Oct. 2019, https://ru.wikipedia.org/wiki/Ибрагимбеков,_Максуд_Мамед_Ибрагим_оглы\#Проза.

[Ibrabimbeyov, Maksud, son of Mamed Ibrabim] 